\title{
Tahajjud Therapy for Stress Coping: Psychoneuroimmunological Perspective
}

\author{
Nur Sophia Matin \\ Airlangga University \\ nursophia81@gmail.com
}

\begin{abstract}
Stress refers to any situation which threatens or is perceived to be threatening welfare of an individual, so that he or she has to cope with that. Coping strategy is a strategy which is used consciously and directly in overcoming the pain or stress. Based on the psychoneuroimmunological perspective, psychological, social, and spiritual stress will affect the hypothalamus. The hypothalamus itself will affect the pituitary and secrete ACTH (Adrenocorticotropic Hormone). The hormone affects the adrenal glands where cortisol is produced. The Tahajjud is conducted in fully sincere, precise, and continuous ways that can foster positive perception and motivation and make coping effective. Such positive emotional response can avoid stress reactions. Importantly, it should be noted that the Tahajjud may also bring stress if the prayer is performed without utmost sincerety. This is shown by the failure to maintain body homeostasis or failure to adapt the changes from diurnal circadian into nocturnal circadian. It is due to cortisol secretion which should be low at night, but, in fact, it is still high because of the Tahajjud activities. A study has proven that the Tahajjud is effective in reducing the secretion of the cortisol hormone as well as improving the immunologic response system. Changes in circadian rhythm and cortisol secretion at night actually enhance the preoccupation of the Tahajjud for those with sincere intentions. Endogenously, activities increase cortisol secretion, whereas a calm environment and darkness decrease the cortisol. Therefore, the secretion of cortisol of the sincere performer of the Tahajjud is at normal levels (homeostasis).
\end{abstract}

Keywords: stress, psychoneuro immunological, coping, tahajjud, cortisol

\section{Medical Benefits of Sholat Tahajjud}

Tahajjud means waking up from sleep. The Tahajjud prayer means a Sunnah prayer performed at night and carried out after sleep despite the sleep length. In the Qur'an, Allah Almighty says in Al-Muzzammil: 1-3 and Al-Isra ': 79. In the first verse, Allah wakes up those sleeping under the blanket at night to perform the Tahajjud prayer. In the second verse, Allah asserts that the Tahajjud prayer is an additional worship related to His promise to exalt those performing the Tahajjud to a higher rank or more powerful position. The Tahajjud prayer has practical benefits, both from the point of view of religion and health, as stated by the Prophet sallallahu alayhi wa salam in a hadith, "Tahajjud prayer can remove sin, bring calmness, and avoid disease" (HR Tirmidhi).

The Prophet's words can be linked to the facts in a study which proves that serenity can improve immune system, reduce the risk of heart disease, and increase life expectation. On the other hand, stress can trigger a person to be susceptible to infections, accelerate the development of cancer cells, and improve metastasis. Thus, theoretically, the physical and mental health of those performing the Tahajjud is guaranteed.

Signal of the hadith of the Messenger of Allah firmly states that there is a close relationship between intensive practice of the Tahajjud prayer and improvement of selfcontrol capability in the form of tranquility. In other words, the Tahajjud performers will be protected from stress. As such, physical health and peace of mind are the immediate results felt by the Tahajjud performers [9].

Adrenal Glands and Cortisol Secretions

The adrenal cortex consists of three zones, namely (1) glomerolusa, which has a distribution of $15 \%$ located on the outer (2) fasciulata, which has a $15 \%$ distribution in the middle, and (3) reticularis is unity as both produce cortisol and androgens [7].

The hormones secreted by the adrenal cortex are cortisol, aldosterone, and androgens. These hormone precursors are the most common cholesterol in lipid droplets in the cytoplasm and from circulating cholesterol (in the form of LDL). LDL receptors are commonly found in the adrenal cortex [7].

The secretion of cortisol and androgens is regulated by ACTH, whereas that of aldosterone is also affected by angiotensin and $\mathrm{K}$-ion concentrations. In addition to the role of ACTH, cortisol secretion is also affected by brain stimulation in response to stress. In fact, cortisol secretion is affected by three responses-stress, ACTH, and diurnal rytme [3].

The role of ACTH in cortisol secretion occurs through the interaction between Hipothalamic-Pituitary Adrenal Axis (HPA). ACTH acts on the fasciulata and reticular zone and is dominant in the regulation of cortisol, androgen, and aldosterone. Meanwhile, ACTH itself is regulated by $\mathrm{CRH}$ (corticotropic releasing hormone) and neurotransmitter.

\section{Effect of Cortisol Against The Immune System}

The interaction between ACTH and cortisol occurs through feedback (negative feedback), at the level of the 
pituitary gland and hypothalamus. The increasing cortisol concentrations inhibit the secretion of ACTH and CRH. The mechanism of cortisol in the gene can decrease RNA synthesis for pro-opiomelanocortin which is also an ACTH precursor [8].

The pattern of cortisol secretion is governed by an endogenous peace maker with suprachiasmatic nucleus in the hypothalamus. This yields "circadian rhythm" impulses. The circadian rhythm causes episodic cortisol and ACTH secretion.

Reichlin states that circadian rhythm disturbances provide the same picture with the result of stress, namely an increase in ACTH. This suggests a change in behavior of the central nervous system as an attempt to control homeostasis so that it will modulate HPA. In the presence of modulation of HPA-axis which causes the rise of the hormone cortisol for 24 hours, there is no low point. Because the low point is usually reached at night.

Circadian rhythm is influenced by changes in sleep patterns, physical and psychological activities, and various diseases such as pituitary gland disorders, chronic renal failure, and CNS disorders. Thus, cortisol secretion may also increase without being bound by circadian rhythms [3].

During stressful conditions, both adrenal cortex activated by ACTH and stimulation by catecholamines can lead to the increasing secretion of the glucortyroid hormone, especially cortisol.

Within 24 hours, ACTH and cortisol have a sedentary pattern. The concentrations of ACTH and cortisol tend to increase in the morning and decrease in the afternoon. The highest levels of Cortisol are from 6:00 to 8:00 pm. Both hormones release it periodically every 30-120 minutes. Factors affecting the rhythm of ACTH and cortisol are (1) intrinsic rhythm and secretion of CRH, (2) feeding cycles, (3) bright and dark stimuli, (4) rhythm found in adrenals played by inactivation of the adrenals.

The biological rhythms of ACTH and cortisol correlate with light and darkness. At night, during dark conditions, there is a decrease in ACTH and cortisol. The lowest levels of cortisol usually occur between 02.00 am because in addition to the absence of light stimulation at that time, the activity is low. And it began to increase in the first hour during sleep.

Adrenal cortex hormone is bound to receptors in the cytoplasm (intracellular receptor). The bonds move in the cell nucleus and interact with chromatin. The results of complementary DNA analysis showed that there was a homology between cortisol receptors, aldosterone, estrogen, progesterone, and thyroid hormone receptors [3].

In summary, the effect of cortisol on the immune response is to suppress the synthesis of immunoglobulin, to decrease PMN cell, lymphocyte and macrophage cell inflation in peripheral blood and cause atrophy of lymphoid tissue in the thymus, spleen, and lymph nodes. [7].

\section{Basic Concepts of Psychoneuroimmunology and Stress}

Psychoneuroimmunology is a branch of science that seeks a two-way relationship; namely the relationship of psychological conditions with the central nervous system (brain) and the relationship of a person's psychological condition with the immune system [4]. In recent developments, the psychoneuroimmunology approach model is used for medical research and is accepted as a relatively holistic and more detailed approach in revealing the mechanisms, both physiobiologically and patoimmunologically viable [7].

The mechanism of increased psychoneuroimmunological resistance can be seen by correlating the changes that occur in hormones and neuropeptides that involve the psychological factors (stress) in the mechanism of changes in body resistance. This psychiatric condition is described as an emotional state that reflects the concept of mental disorders [6].

Broadly speaking, the medicopsychological approach of stress is the basic paradigm of psychoneuroimmunology. In a medical standpoint, according to Hans Seley, a physiologist and stress expert, stress is a nonspecific body response to action or demands on it. Stress is an automatic response of the body that is adaptive to any treatment that cause physical or emotional changes that aim to maintain optimal physical condition of an organism. This physiological reaction is referred to as general adaptation syndrome (GAS) [6].

From a psychological point of view, stress is defined as an internal state caused by the body's psychological needs, or caused by potentially dangerous environmental or social situations, posing challenges, generating changes or requiring a person's defense mechanism [6].

Although pathophysiologically the onset of physical abnormalities associated with psychological disorders has not been entirely explicable, there is already considerable evidence from expert research that may be useful. Psychic disorders that can cause psychosomatic disorders were followed by physiological changes in one's body. Physiological changes are closely related to the disruption of the vegetative nervous system, the endocrine system, and the immune system. Therefore, recent physiological changes can be explained in the field of psychoneuroimmunology. The changes of the three systems occur simultaneously and overlap [1].

\section{Psychoneuroimmunology Sholat Tahajjud}

The Tahajjud prayer which is run allegedly with full sincere, solemn, precise, sincere, and continuation can foster positive perception and motivation and effective coping. And, a positive emotional response can avert a stressful reaction [9].

In terms of controlling emotional responses, attempts can be made with some strategic alternatives. Taylor advocated a cognitive redefinition strategy, in which a person is helped to see the problem from a positive point of view. Meanwhile, Lazarus advocated a cognitive restructuring strategy, namely the attempt to change the 
perception to be more realistic and constructive about stressors [9].

People who practice the Tahajjud prayer will meet the above two strategies because the essence of wisdom that can be obtained from prayer itself are a realistic life and being always optimistic in the readiness to face various problems of life so that people remain constructive.

In an optimistic attitude, people will be awake and remain in homeostasis conditions. Homeostasis occurs because of feedback mechanisms that limit excessive reactions and maintain normal conditions. Homeostatic failure is mainly due to failure of feedback mechanisms, which can lead to excessive stress.

It is now known that the central nervous system transmits neurological information to biological and physiological responses through various hormones, neuropeptides, neurotransmitters, hypothalamic Pituitary Adrenal Axis (HPAA), and autonomic nervous system. The arrangement is proven to have a very important role in emotional, optimistic, and stress reactions, and it is associated with immune responses [2].

A variety of emotional conditions, both positive and stressful, can lead to HPAA activity. It also results in attraction of positive and negative attitudes of emotional atmosphere: calm, optimistic, happy, anxious, difficult, and stress. The stimuli that arrive at the parvocellular division of the preventicular nucleus (mpPVN) in the hypothalamus will cause CRF secretion, which primarily plays a central role in CRF stress suppression reactions in a positive emotional state. CRF then triggers the HPAA reaction. In addition, the hypothalamus mpPVN nucleus is also associated with the Ceruleus locus (LC), where most NE neurons (norepinephrine) have a CRF respecter. Thus, HPAA activity also activates the autonomic nervous system [2].

CRF secretion by the hypothalamus mpPVN neuron depends on the balance between stimulating conditions and inhibiting conditions, synthesis and secretion. Neurotransmitters that are known to increase CRF secretion are acetylcholine and serotonin, while those that inhibit are cortisol and Gamma Aminobutyric Acid (GABA). GABA is particularly prevalent in the hippocampus area according to the hippocampus that acts as a controller of the emotions and controls of HPAA [9].

The limbic system of amygdala and hippocampus is the part of the brain that regulates motivation, emotional response, and rejection reactions to unwanted stimuli. Various studies have concluded that the hippocampus maintains basal tone or controls HPAA, and together with other limbic structures it serves to provide past information, whether a stimulus is a stressor or not. The amygdala receives an impulse or information of emotional stimuli (stressors) from the sensory system, the brain stem, through the thalamus that allows immediate reaction to maintain the body. In addition, the amygdala also receives information from the cognition centers and sensory associations in the cortex [5].

Based on that information, an analysis of stimuli by the amygdala will produce an emotional response which is then fed to the left and right prefrontal and hippocampal prefrontal cortex. This feedback raises awareness of emotional response and attitude adjustment. When the Tahajjud prayer is accepted as a stressor, integrally, the amygdala sends information to the Ceruleus locus (LC) that triggers the autonomic system, transmitted to the hypothalamus, resulting in CRF secretion [9].

Instead, if the Tahajjud prayer brings a positive perception, the amygdala will send information to Ceruleus locus (LC) that activates the autonomic nervous reactions. Through the hypothalamus, secrete neurotransmitters, endorphins and enkepalin, serve as pain relievers and CRF crispre controls in excess. As a result, HPAA in secreting Adrenocorticotropic hormone (ACTH) is also stable under control. A decrease in ACTH will stimulate a decrease in the production of cortisol in the adrenal cortex and catecholamines (epinephrine and norepinephrine), in adrenal medulla with alpha $(\mathrm{Ra})$ receptors, and the beta $(\mathrm{Rb})$ receptor is stable so that it affects the positive immune system[9].

In a state of stress, there is a substance that resembles beta carboline, the GABA antagonist that is thought to cause a decrease in the number of GABA receptors. Reduced GABA receptors lead to reduced resistance to the onset of anxiety and ease stress reactions. Thus, it can be understood that in a calm, happy, optimistic, and hopeful state, (influence of Tahajjud prayer), there is cortisol secretion, GABA antagonists and normal positive GABA synthesis [9].

\section{REFERENCES}

[1] Ader, R. Felten, D. L. And Cohen, N. Psychoneuroimmunology. Sandiego: Academic Press. 2007.

[2] Bonica, J. Anatomic and Physiologic Basic of Nociception and Pann. London: Lia and Febriger. 2010.

[3] Guyton, Arthur, C \& Hall, John, E. Human Physiology and Diseases Mechanism, (11th Ed) terjemahan oleh Irawati. 2007. Jakarta: EGC. 2001.

[4] Hawari, D. Global Effect HIV \& AIDS Dimensi Psikoreligi. FKUI: Jakarta. 2006.

[5] Ikawati, Zullies. Farmakoterapi Penyakit Sistem Syaraf Pusat. Yogyakarta: Bursa Ilmu. 2011.

[6] Nursalam. Asuhan Keperawatan pada Pasien Terinfeksi HIV \& AIDS. Jakarta: Salemba Medika. 2007.

[7] Rizaldy, Erlangga. Hubungan Shalat Tahajjud dengan Perubahan Kadar Kortisol dan Skor Tingkat Stres pada Pasien HIV dan AIDS. Skripsi. Jakarta: Universitas Islam Negeri Syarif Hidayatullah. 2013.

[8] Sherwood, Lauralee. Fisiologi Manusia. Jakarta: EGC. 2005.

[9] Sholeh, Moh. Terapi Sholat Tahajjud. Jakarta: Mizan Publika. 2012. 